\title{
Христианская эсхатология и социальная практика Церкви
}

\author{
протоиерей Дионисий Мартышин ${ }^{1}$ \\ Кафедра Православной Культуры и Теологии \\ Межрегиональной Академии Управления Персоналом \\ Киев, Украина \\ dionisk79@mail.ru
}

\author{
священник Павел Бочков ${ }^{2}$ \\ Норильск, Украина \\ frpavel@inbox.ru
}

\begin{abstract}
Rev. Dionisij Martyshin, Rev. Pavel Bochkov, Christian eschatology and social practices of the Church, Elpis, 17 2015: 139-144.
ks. Dionisij Martyshin, ks. Pavel Bochkov, Chrześcijańska eschatologia i socjalna praktyka Cerkwi, Elpis, 17 2015: 139-144.

Abstract: The scientific article presents an endeavor of theological analysis of global processes of modern civilization on the basis of Christian historiosophy, eschatology and social doctrine of the Orthodox Church. The authors avoid scholastic schemes of presentation of teaching of the last fates of the world; they demonstrate everything the most characteristic for Christian world view: joy in God, hope, active social position of a believer in difficult and contradictory context of globalization. The article puts the issue of eschatology in a wide context of culture and Christian world view, develops a theme of Christian philosophy, history in the context of modern world challenges.
\end{abstract}

Streszczenie: Artykuł jest próbą teologicznej analizy globalnych procesów cywilizacyjnych na podstawie chrześcijańskiej filozofii historii, eschatologii i nauki społecznej Kościoła prawosławnego. Autorzy unikają scholastycznych schematów prezentacji doktryny o końcu świata i przedstawiają wszystkie charakterystyczne elementy chrześcijańskiej eschatologii: radości w Bogu, nadziei, aktywnej pozycji społecznej wierzącego w złożonych i sprzecznych warunkach globalizacji. Artykuł przedstawia zagadnienia eschatologiczne w szerszym kontekście kultury i chrześcijańskiego rozumienia świata, odsłaniając temat chrześcijańskiej filozofii historii w kontekście wyzwań współczesnego społeczeństwa.

\begin{abstract}
Аннотация: В научной статье сделана попытка богословского анализа глобальных процессов современной цивилизации на основе христианской историософии, эсхатологии и социальной доктрины Православной Церкви. Авторы избегают схоластических схем изложения учения о последних судьбах мира, показывая все самое характерное для христианского миросозерцания: радость в Боге, надежду, активную социальную позицию верующего человека в сложных и противоречивых условиях глобализации.

Статья помещает проблему эсхатологии в широкий контекст культуры и христианского миропонимания, раскрывая тему христианской философии истории в контексте вызовов современного общества.
\end{abstract}

Keywords: historiosophy, eschatology, civilization, geopolitics, mission, the Church, social practices

Słowa kluczowe: filozofia historyczna, eschatologia, cywilizacja, geopolityka, misja, Kościół, praktyka społeczna

Ключевые слова: историософия, эсхатология, цивилизация, геополитика, миссия, Церковь, социальная практика

В последнее время в свет вышло немало книг, связанных с проблематикой эсхатологической мысли Православной Церкви. Но до сих пор понятие «эсхатология» для многих богословов и религиозных мыслителей остается крайне неопределенным. Самые

\footnotetext{
${ }^{1}$ Протоиерей Дионисий Мартышин, доктор богословия (ThD), заведующий кафедрой православной культуры и теологии Межрегиональной Академии Управления Персоналом, доцент Киевской Духовной Академии и Семинарии, член Синодального отдела религиозного образования и катехизации УПЦ. Адрес для корреспонденции: 03162, Украина, г. Киев - 162, бул. Ромена Роллана, д. 5 «Б», кв. 41. 2 Священник Павел Бочков, доктор богословия (ThD), настоятель храма свт. Луки Архиепископа Красноярского г. Норильска, клирик Норильской епархии. Адрес для корреспонденции: 663318, Красноярский край, г. Норильск, ул. Талнахская, д. 38, кв. 50.
}

разные смыслы и идеи вкладываются в понятия, касающиеся философии истории, историософии и эсхатологии. В нашей статье ключевым понятием является определение «историософия». Это слово означает понимание, истолкование каких-либо исторических явлений с определённых мировоззренческих позииий. Дословный перевод означает историческая мудрость. Очень часто слово «историособия» переводят как философия истории. В нашем случае размышляя об историософии, мь подразумеваем христианскую эсхатологическую мудрость, основанную на Священном Писании, Священном Предании Церкви, богословских работах святых отияов и научных изысканиях религиозных мыслителей. Человеческая история без христи- 
анской историософии превращается, по замечанию социолога профессора Питирима Сорокина, в «историю, похожую на труп» ${ }^{3}$.

В общем, для одних эсхатология - это философское обозрение прошлого и прогнозирование будущего человечества, для других - это исследование общих законов социального развития и духовного становления общества. Ну, а для третьих, эсхатология - теория исторического познания и изучение религиозной мифологии. Сообразно с этими философскими определениями эсхатологию можно определить как богословское обозрение истории человечества или как познание законов духовной и общественной жизни в истории. Иными словами, как говорит митрополит Филарет (Вахромеев), «эсхатология говорит нам о том, каким должно быть наше отношение к миру, в котором мы живем и совершаем свой духовный путь» ${ }^{4}$.

Сегодня христианская философия истории и православная эсхатология интересует не только верующих православных христиан, но и самые широкие круги светской науки. Философия истории представляет собой область философского знания, охватывающего онтологические вопросы исторического процесса такие, как смысл и направление истории ${ }^{5}$. Она отвечает на вопрос об объективных закономерностях и духовно-нравственном смысле исторического процесса, о путях реализации человеческих сущностных сил в истории, о возможностях обретения общечеловеческого единства ${ }^{6}$.

Для светской науки и теории познания мира именно эсхатология создает возможность и необходимость разработки историософии. Появление историософии является одним из признаков складывания «мира» («цивилизации»). Человечество, образно выражаясь, отказывается от «бездомного» варианта «исхода» и начинает «строительство» своего «дома» 7 .

Проанализировав философию истории, остановим свое внимание на понимании эсхатологии как науки. Существует два похода в определении этой науки: эсхатология частная - учение о загробной жизни человеческой души, и эсхатология общая - учение о цели космоса, мироздания и человеческой истории ${ }^{8}$.

Сорокин П. А. Николай Бердяев // Н. А. Бердяев: pro et contra. Кн. 1 / Сост., вступ. ст. и прим. А. А. Ермичева. - СПб., 1994. С. 477.

4 [Филарет (Вахромеев), митрополит]. Выступление Митрополита Минского и Слуцкого Филарета, Патриаршего Экзарха всея Беларуси, Председателя Синодальной Богословской Комиссии Русской Православной Церкви // Эсхатологическое учение Церкви (Москва, 14-17 ноября 2005 г.). Материалы богословской Конференции Русской Православной Церкви. - М.: Синодальная Богословская комиссия, 2007. С. 19.

Щёкин Г. В. Социальная философия (теория социального развития): Монография. - К.: МАУП, 1996. С. 5.

6 Философия истории: Учеб. Пособие / Под. ред. проф. А. С. Панарина. - М.: Гардарики, 2001. С. 8.

Пиков Геннадий. Эсхатология и христианская историософия // Эсхатологический сборник / Отв. ред. Д. А. Андреев, А. И. Неклесса, В. Б. Прозоров. - СПб., 2006. С. 97.

8 Аверинцев Сергій. Софія-Логос. Словник. 2-е видання. - К., 2004. C. 95 .
Учитывая весь комплекс проблем рассматриваемых эсхатологией, можно условно дать интегральное рабочее определение эсхатологии как богословской и философской науки. Эсхатология - христианская наука, раскрывающая духовно-нравственный смысл, предназначение, цель и конец человеческой истории.

Безусловно, учитывая объективность научных исследований, необходимо отметить, что в современной церковной жизни есть разные подходы к эсхатологии как науке. Одни определяют, ее как «учение о последних вещах, о конечной судьбе мира и человека», другие как часть догматического богословия, повествующего о втором пришествии Христа и загробной жизни человека. А третьи, и вовсе, не вникая в богословие Церкви, запугивают людей понятием «эсхатология», выдумывая разные ужасы и предсказания «старцев» о последних днях и временах человеческой истории.

Своеобразие эсхатологии Церкви состоит в том, что эта наука не сводится к системе схоластических понятий «школьного богословия» и «казенных» определений философии. Эсхатологическая мысль представляет собой не столько «обетование грядущего конца мира», сколько «творческий порыв настоящего» современного христианства. Известный богослов, профессор, протоиерей Сергий Булгаков говорил о том, что «перед лицом такого фактического положения вещей представляется неправильным, если догматическая доктрина, излагаемая в схоластических руководствах, выдает свое учение за авторитетные и обязательные догматы Церкви и с нарочитой настойчивостью требует им подчинения как таковым. В ответ на подобное требование следует совершенно решительно и определенно установить, что здесь имеет место преувеличение и недоразумение» ${ }^{9}$.

Современной богословской мысли необходима новая парадигма изучения эсхатологии в контексте философии истории, а не через призму схоластических учебников догматики, которые по мысли видного западного исследователя православного богословия профессора Карла Христиана Фельми, «едва ли наилучшим образом отвечают православному церковному опыту» ${ }^{10}$.

Эсхатология несет в себе большой нравственно-этический импульс преобразования человеческой истории. Иными словами эсхатология не только наука, но и социальная практика бытия христианина. Рассматривать и изучать христианскую эсхатологию следует именно в этом контексте, т. е. в неразрывной связи богословия с практикой христианской жизни и богослужением Церкви. Протоиерей Эммануил Клапсис считает, что эсхатология не только занимается вопросами, касающимися конца истории, суда, жизни после смерти, но и важным аспектом «присутствия Бога в истории как освобождающей надежды» ${ }^{11}$.

\footnotetext{
9 Булгаков Сергий, прот. Невеста Агнца. - М., 2006. С. 404.

10 Фельми. К. Х. Введение в современное православное богословие. - М., 1999. С. 273.

11 Клапсис Эммануил, прот. Творение и эсхатон // Эсхатологиче-
} 
Эсхатологическая мысль Православной Церкви напрямую связана с социальным служением, с теми процессами преобразования мира по слову Евангелия, которые видный русский философ Николай Бердяев назвал «активно-творческим эсхатологизмом», призывающим к преображению мира ${ }^{12}$. Христианин «должен активно идти навстречу» ${ }^{13}$ Христу Спасителю и Его грядущему Царству.

Предметный мир любой науки или ее части - теории характеризуется двумя понятиями: объектом науки и ее предметом. Объект - это часть реальности, которая попадает в поле интереса богословской науки, отражается ею. Предмет - это какие-либо свойства, стороны, аспекты объекта, которые непосредственно изучаются наукой. Отсюда объектом эсхатологии является богословие Церкви, историософия религиозных мыслителей. Сами же духовно-нравственные координаты пути человечества к Богу, предназначение, завершение человеческой истории в христианском прочтении являются предметом исследования. При этом необходимо подчеркнуть, что «эсхатология является областью вопросов, а не ответов, тайн, а не очевидности, упований и надежд, а не безапелляционных утверждений. Много из того, что касается будущей судьбы мира и человечества, открыто нам в Священном Писании и Предании Церкви, но многое остается в сокровенной глубине божественных тайн» ${ }^{14}$.

Отсюда радикальное утверждение известного греческого православного богослова Христоса Яннараса, который считает, что «Церковь ничего не знает об эсхатологии. Она вверяет себя любви Божией и надеется. Это доверие является иным видом знания - знания не психологического или «мистического» - а знания, которое возникает из отношения и которое мы, люди, вкушаем всякий раз, когда воистину влюблены. Такое знание приносит евангельское слово, поэтому язык церковный не повинуется языку науки, нашему повседневному языку, пределы которого являются пределами нашего мира» ${ }^{15}$.

Эсхатологическое прозрение Церкви прекрасно выразил святой апостол Павел: «Теперь мы видим как бы через тусклое стекло, гадательно, тогда же лицом к лицу; теперь знаю я отчасти, а тогда познаю, подобно как я познан» (1 Кор 13:12). Об этом возвещает и святой апостол Иоанн: «Возлюбленные! Мы теперь дети

ское учение Церкви (Москва, 14-17 ноября 2005 г.). Материалы богословской Конференции Русской Православной Церкви. - М.: Синодальная Богословская комиссия, 2007. С. 44.

12 Бердяев Н. А. Самопознание: Сочинения. - М. - Харьков, 2001. C. 551 .

13 Там же. С. 559.

14 Иларион (Алфеев), митр. Конец времен: Православное учение. М.: Эксмо, 2014. С. 23.

15 Яннарас Христос. Эсхатология: конец времени или освобождение от времени? // Эсхатологическое учение Церкви (Москва, 14-17 ноября 2005 г.). Материалы богословской Конференции Русской Православной Церкви. - М.: Синодальная Богословская комиссия, 2007. С. $20-21$.
Божии; но еще не открылось, что будем. Знаем только, что увидим Его, как Он есть» (1 Ин 3:2).

Митрополит Пергамский Иоанн (Зизиулас) говорит: «Синтез истории с эсхатологией создает то, что мы в полном смысле слова могли бы назвать таинственной природой Церкви» ${ }^{16}$. «Здесь, несомненно, - по словам видного западного богослова Ханса Урса фон Бальтазара, - мировая история превращается в теологическое событие» ${ }^{17}$. В этом уникальность, неповторимость и жизненность эсхатологии Православной Церкви.

Современная философия истории, христианская эсхатологическая мысль, футурология связаны с именами выдающихся западных философов Альберта Швейцера, Освальда Шпенглера ${ }^{18}$, Арнольда Джозефа Тойнби ${ }^{19}$, Карла Барта ${ }^{20}$, Рудольфа Бультмана ${ }^{21}$.

Огромный вклад в развитие христианской эсхатологии в её теоретическом аспекте внесли известные религиозные мыслители и богословы: Николай Бердяев $^{22}$, Семен Франк ${ }^{23}$, Николай Федоров ${ }^{24}$, протоиерей Сергий Булгаков ${ }^{25}$, Антон Карташев ${ }^{26}$, протопресвитер Александр Шмеман ${ }^{27}$, протоиерей Александр Мень ${ }^{28}$. Отдельного внимания заслуживают фундаментальные исследования митрополита Волоколамского Илариона (Алфеева) «Конец времен: Православное учение» и профессора Московской духовной академии А. И. Осипова «Из времени в вечность: посмертная жизнь души».

Современная проблематика эсхатологии связана с именами известных христианских мыслителей и западных богословов: Юргена Мольтмана, Николаса Томаса Райта ${ }^{29}$, Томаша Шпидлика, Ганса Кюнга, Девида

16 Иоанн (Зизиулас), митр. Бытие как общение: Очерки о личности и Церкви / Предисл. прот. Иоанна Мейендорфа; Пер. с англ. Д. М. Гзгзяна. - М.: Свято-Филаретовский православно-христианский институт, 2006. С. 189.

17 Бальтазар X. У. Целое во фрагменте: Некоторые аспекты теологии истории. - М.: Истина и Жизнь, 2001. С. 184.

18 Подробнее см.: Шпенглер О. Закат Европы. Очерки морфологии мировой истории: Гештальт действительность / Освальд Шпенглер; пер. с нем., вступ. ст. и примеч. К. А. Свасьяна. - М., 2007; Шиенглер Освальд. Годы решений / Пер. с нем. В. В. Афанасьева; Общая редакция А. В. Михайловского. - М., 2006.

19 Подробнее см.: Тойнби А. Дж. Постижение истории. / Пер. с англ. - М., 2008; Тойнби А. Дж. Пережитое. Мои встречи / Пер. с англ. M., 2003.

20 Подробнее см.: Барт К. Мгновения / Пер. с нем. - М., 2006; Барт К. Очерк догматики. / Пер. с нем. Ю. А. Кимелева. - СПб., 2000.

21 Подробнее см.: Бультман Р. История и эсхатология. Присутсвие вечности: Монография / Р. Бультман. Пер. с англ. А. М. Руткевич. - М., 2012

22 Подробнее см.: Бердяев Н. А. Дух и реальность / Н. А. Бердяев; Вступ. ст. и сост. В. Н. Калюжного. - М., - Харьков, 2003; Бердяев Н. А. Смысл творчества: Опыт оправдания человека / Н. А. Бердяев. М., Харьков, 2004.

23 Свет во тьме. Опыт христианской этики и социальной философии. - М., 1998.

24 Федоров Н. Ф. Философия общего дела. В 2-х тт. - Т. 1. - М., 2003.

25 Булгаков Сергий, прот. Невеста Агнца. - М., 2006.

26 Карташов А. В. Воссоздание Святой Руси. - М., 1991.

27 Шмеман А., прот. Литургия и Предание. - К., 2005.

28 Мень А., прот. Читая Апокалипсис. - М., 2000.

29 Райт T. Главная тайна Библии: Смерть и жизнь после смерти в 
Бентли Харта, Христоса Яннараса, митрополита Георгия (Ходра), митрополита Иоанна (Зизиуласа).

Исследовательскими импульсами в исследовании процессов глобализации, современной экономики, политики в русле религиозной прогностики и эсхатологии могут послужить философские труды А. С. Панарина, одного из наиболее ярких и самобытных русских социальных и религиозных мыслителей второй половины ХХ столетия.

При подробном изучении социальных законов развития мира и эсхатологической перспективы будут всегда востребованы научные труды видного украинского ученого, специалиста в области социальной философии, социологии, психологии, религиоведения и управления человеческими ресурсами профессора Г. В. Щёкина ${ }^{30}$.

Важно отметить, что буквально все сферы человеческого бытия относятся к эсхатологии. Личные переживания, надежды, упования, активная социальная и гражданская позиция, домашние и храмовые молитвы, заупокойные прошения за умерших близких и родных, память о смерти и Суде Божьем - все эти сферы жизни каждого человека относятся к области эсхатологии Православной Церкви. Не случайно известный православный богослов двадцатого столетия, протопресвитер Александр Шмеман подчеркивал, что «все христианское богословие эсхатологично, как эсхатологично и все христианское переживание жизни» ${ }^{31}$. В этом контексте совершенно уместен вопрос о практическом значении обращения к эсхатологическому наследию Православной Церкви. Выдающийся церковный иерарх, видный богослов, митрополит Волоколамский Иларион (Алфеев) отмечает, что «вне эсхатологического измерения христианство теряет смысл, перестает быть самим собой» ${ }^{32}$.

Христианская эсхатология интегральная и целостная ветвь христианского богословия объединяет стремление христианина к грядущему Царству Божьему и его активную социальную позицию в земной жизни, дает возможность современному христианству преодолеть дуализм, разделение, раскол, дихотомию бытия, греховную инертность и пассивность. Видный западный богослов Ганс Кюнг напоминает: «Вступить в сферу господства Христа, означает - и это основная идея богословия - участвовать в «дедемонизации»

христианстве / Том Райт; [пер. с англ. М. И. Завалова]. - М., 2009.

Подробнее см.: Щёкин Георгии. Система управления человеческими ресурсами. - К.: ДП «Издат. дом «Персонал», 2009; Щёкин Георгий. Организация и психология управления персоналом: Учеб.-метод. пособие. - К.: МАУП, 2002; Щокін Г. В. Закони соціального розвитку і управління. - К.: МАУП, 2006; Щокін Г. В. Основи політичної науки. - К.: МАУП, 2006; Щокін Г. В. Управління суспільним розвитком: загальна концепція. - К.: МАУП, 2005; Людство і віра: Навч.-метод. Посіб.: [У 3 т.] / Авт. - уклад. Г. Щокін. К.: МАУП, 2002. - Т. I.

31 Шмеман Александр. Богослужение и эсхатология // Шмеман А., прот. Сборник статей. 1947 - 1983 / Сост. Е. Ю Дорман; А. И. Кьрлежева. - М., 2009. С. 303.

32 Иларион (Алфеев), митр. Конец времен: Православное учение. М.: Эксмо, 2014. С. 16. идолов этого мира с целью достигнуть более человечного, более христианского общества» ${ }^{33}$.

Эсхатология Церкви является не перспективой неопределимого конца мира, а «перспективой каждого мгновения жизни» ${ }^{34}$. В молитве, евхаристическом благодарении и социальном служении христианина эсхатология раскрывается как начало, настоящее и конец человеческой истории. «Эсхатология составляет центральный и главный аспект экклезиологии, начала Церкви, концепции, которая составляет своеобразие Церкви, но и поддерживает и вдохновляет ее в ее бытии. Но эсхатология, чтобы быть подлинной, должна быть связана не с абстрактной идеей будущего, но с керигматическим учением Господа о Царстве Божием. Именно это «царственное богословие» побудило все экклезиологические соображения поставить на первое место ожидаемое Царство Божие. Все принадлежит Царству. Церковь в своем институциональном выражении на совершает реальность; она только готовит путь к Царству в том смысле, что она является ее образом. Вот почему, будучи еще одним человеческим институтом для историка и социолога, Церковь для богослова является прежде всего тайной, и мы очень часто называем ее образом грядущего Царства» ${ }^{35}$.

Эсхатологическая парадигма ${ }^{36}$ Церкви не уводит верующего от насущных вопросов социального бытия, как утверждают скептики и циничные прагматики. Богословие Церкви является мощным инструментом конструирования, прогнозирования социальной реальности человека. Известный западный экзегет, епископ Даремский Том Райт объясняет: «Правление небес, правление Бога должно стать реальностью в мире, тогда оно приведет к спасению как уже сегодня, так и в будущем, причем это будет и спасение для людей, и одновременно, через спасенных людей, спасением всего мира. Таково твердое основание миссии Церкви» ${ }^{37}$.

Подводя итог, отметим.

Во-первых, сегодня открываются возможности для кардинального изменения роли эсхатологии в самой богословской науке, в преобразовании церковно-приходской и общественной жизни современного социума. Православная эсхатология является непременной составной

Кюнг Ганс. Вечная жизнь? / Пер. с нем. - М.: Издательство ББИ, 2014. C. 326.

34 Бердяев Н. А. Дух и реальность / Н. А. Бердяев; Вступ. ст. и сост. В. Н. Калюжного. - М., - Харьков, 2003. С. 564.

35 Василиадис Петрос. Эсхатологическая экклезиология: выходя за пределы традиционной евхаристической экклезиологии // Эсхатологическое учение Церкви (Москва,14-17 ноября 2005 г.). Материалы богословской Конференции Русской Православной Церкви. - М.: Синодальная Богословская комиссия, 2007. С. 90.

36 Подробнее см.: Бочков П. В., свящ. Эсхатологическая парадигма и ее роль в богословской науке: к постановке вопроса // Актуальные проблемы социально-гуманитарных наук / материалы межвузовской научно-практической конференции студентов, аспирантов и молодых ученых с международным участием / - Челябинск : Уральская Академия, 2014. С. $8-15$.

37 Райm T. Главная тайна Библии: Смерть и жизнь после смерти в христианстве / Том Райт; [пер. с англ. М. И. Завалова]. - М., 2009. C. 250. 
частью цельной богословской системы православного богословия. Еще до недавнего времени ее проблематика либо ограничивалась последними главами учебника по догматике, либо фокусировалась на загробной участи души после смерти. Поэтому эсхатология, несмотря на пробудившийся к ней в последнее время интерес в сфере политологии, геополитики, экклезиологии, пока остается недостаточно исследованным проблемным полем православной богословской мысли.

Во-вторых, Эсхатология Церкви - это, в первую очередь, богословие надежды. Попытка бегства хри- стианина от реальных процессов жизни современного общества только усугубляет трагедию современного человека. Возрождение эсхатологической надежды, пламенной, горячей веры, апостольского оптимизма, социальной активности в преображении мира, в победе над силами зла, насилия и авторитарности, уничтожающей богоданную свободу человека - залог выхода общества из любого кризиса и пустыни от чаяния. Христианин призван Богом возжигать в сердцах людей пламя надежды, любви, веры, радости и активного действия на нивах человеческих страданий и лишений.

\section{Источники и литература}

Аверинцев Сергій. Софія-Логос. Словник. 2-е видання. - К., 2004.

Бальтазар Х. У. Целое во фрагменте: Некоторые аспекты теологии истории. - М.: Истина и Жизнь, 2001.

Барт К. Мгновения / Пер. с нем. - М., 2006.

Барт К. Очерк догматики. / Пер. с нем. Ю. А. Кимелева. СПб., 2000.

Бердяев Н. А. Дух и реальность / Н. А. Бердяев; Вступ. ст. и сост. В. Н. Калюжного. - М., Харьков, 2003.

Бердяев Н. А. Самопознание: Сочинения. - М. - Харьков, 2001.

Бердяев Н. А. Смысл творчества: Опыт оправдания человека / Н. А. Бердяев. - М., - Харьков, 2004.

Бочков П. В., свящ. Эсхатологическая парадигма и ее роль в богословской науке: к постановке вопроса // Актуальные проблемы социально-гуманитарных наук / материалы межвузовской научно-практической конференции студентов, аспирантов и молодых ученых с международным участием / - Челябинск: Уральская Академия, 2014. С. 8 - 15.

Булгаков Сергий, протоиерей. Невеста Агнца. - М., 2006.

Бультман Р. История и эсхатология. Присутсвие вечности: Монография / Р. Бультман. Пер. с англ. А. М. Руткевич. - M., 2012.

Василиадис Петрос. Эсхатологическая экклезиология: выходя за пределы традиционной евхаристической экклезиологии // Эсхатологическое учение Церкви (Москва, 14-17 ноября 2005 г.). Материалы богословской Конференции Русской Православной Церкви. - М.: Синодальная Богословская комиссия, 2007. С. 89 - 101.

Иларион (Алфеев), митрополит. Конец времен: Православное учение. - М.: Эксмо, 2014.

Иоанн (Зизиулас), митрополит. Бытие как общение: Очерки о личности и Церкви / Предисл. прот. Иоанна Мейендорфа; Пер. с англ. Д. М. Гзгзяна. - М.: Свято-Филаретовский православно-христианский институт, 2006.

Карташов А. В. Воссоздание Святой Руси. - М., 1991.

Клапсис Эммануил, протоиерей. Творение и эсхатон // Эсхатологическое учение Церкви (Москва, 14-17 ноября 2005 г.). Материалы богословской Конференции Русской Православной Церкви. - М.: Синодальная Богословская комиссия, 2007. С. $43-50$.
Кюнг Ганс. Вечная жизнь? / Пер. с нем. - М.: Издательство ББИ, 2014.

Людство і віра: Навч.-метод. Посіб.: [У 3 т.] / Авт. - уклад. Г. Щокін. - К.: МАУП, 2002. - Т. І.

Мень А., прот. Читая Апокалипсис. - М.: 2000.

Пиков Геннадий. Эсхатология и христианская историософия // Эсхатологический сборник / Отв. ред. Д. А. Андреев, А. И. Неклесса, В. Б. Прозоров. - СПб., 2006. С. 85 - 97.

Райm Т. Главная тайна Библии: Смерть и жизнь после смерти в христианстве / Том Райт; [пер. с англ. М. И. Завалова]. - M., 2009.

Свет во тьме. Опыт христианской этики и социальной философии. - М., 1998.

Сорокин П. А. Николай Бердяев // Н. А. Бердяев: pro et contra. Кн. 1 / Сост., вступ. ст. и прим. А. А. Ермичева. - СПб., 1994. - С. 477 - 482.

Тойнби А. Дж. Пережитое. Мои встречи / Пер. с англ. - М., 2003.

Тойнби А. Дж. Постижение истории. / Пер. с англ. - М., 2008.

[Филарет (Вахромеев), митрополит]. Выступление Митрополита Минского и Слуцкого Филарета, Патриаршего Экзарха всея Беларуси, Председателя Синодальной Богословской Комиссии Русской Православной Церкви // Эсхатологическое учение Церкви (Москва, 14-17 ноября 2005 г.). Материалы богословской Конференции Русской Православной Церкви. - М.: Синодальная Богословская комиссия, 2007. С. 12 - 19.

Федоров Н. Ф. Философия общего дела. В 2-х тт. — Т. 1. - М., 2003.

Фельми. К. Х. Введение в современное православное богословие. - М., 1999.

Философия истории: Учеб. Пособие / Под. ред. проф. А. С. Панарина. - М.: Гардарики, 2001.

Шмеман А., протоиерей. Литургия и Предание. - К., 2005.

Шмеман Александр. Богослужение и эсхатология // Шмеман А., прот. Сборник статей. 1947 - 1983 / Сост. Е. Ю Дорман; А. И. Кьрлежева. - М., 2009. С. 299 - 306.

Шмеман А., прот. Сборник статей. 1947 - 1983 / Сост. Е. Ю Дорман; А. И. Кырлежева. - М., 2009.

Шиенглер О. Закат Европы. Очерки морфологии мировой истории: Гештальт действительность / Освальд Шиен- 
глер; пер. с нем., вступ. ст. и примеч. К. А. Свасьяна. M., 2007.

Шиенглер Освальд. Годы решений / Пер. с нем. В. В. Афанасъева; Общая редакция А. В. Михайловского. - М., 2006.

Щёкин $Г$. В. Социальная философия (теория социального развития): Монография. - К.: МАУП, 1996.

Щёкин Георгий. Организация и психология управления персоналом: Учеб.-метод. пособие. - К.: МАУП, 2002.

Щёкин Георгий. Система управления человеческими ресурсами / Г. В. Щёкин: монография. - К.: ДП «Издат. дом «Персонал», 2009.
Щокін Г. В. Закони соціального розвитку і управління. - К.: МАУП, 2006.

Щокін Г. В. Основи політичної науки. - К.: МАУП, 2006.

Щокін Г. В. Управління суспільним розвитком: загальна концепція. - К.: МАУП, 2005.

Яннарас Христос. Эсхатология: конец времени или освобождение от времени? // Эсхатологическое учение Церкви (Москва, 14-17 ноября 2005 г.). Материалы богословской Конференции Русской Православной Церкви. - М.: Синодальная Богословская комиссия, 2007. С. 20 - 24.

Rozmiar artykułu: 0,6 arkusza wydawniczego 
ISSN 1508-7719

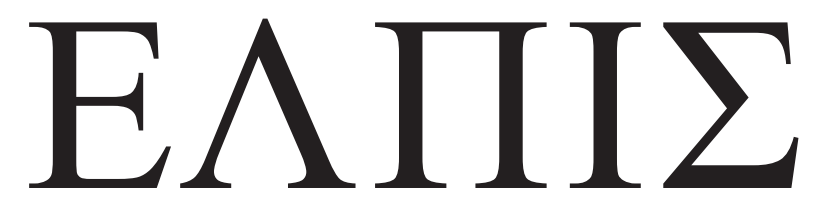

CZASOPISMO TEOLOGICZNE KATEDRY TEOLOGII PRAWOSŁAWNEJ UNIWERSYTETU W BIAŁYMSTOKU

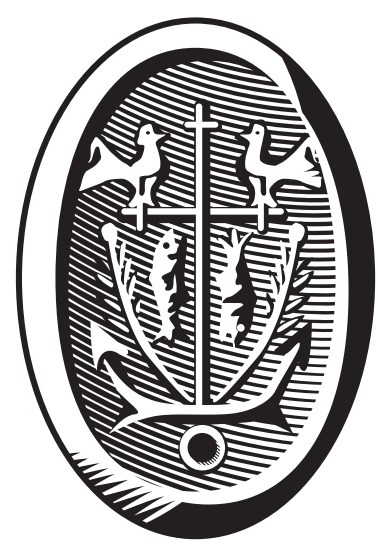

ADRES REDAKCJI

15-097 Białystok, ul. M. Skłodowskiej-Curie 14 tel. 85 745-77-80, e-mail: redakcja@elpis.edu.pl www.elpis.uwb.edu.pl 